\title{
JUURNAL.RU
}

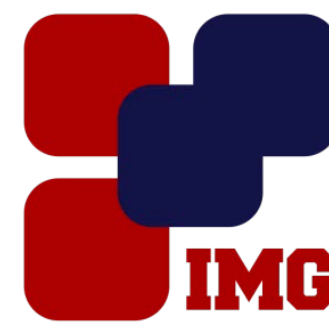

IVANov
Management
GROUP

Карпов В.А.

Калужский государственный университет им. К.Э.Циолковского

Калуга, Россия

doi: 10.18411/lj-31-01-2017-4-11

idsp 000001:lj-31-01-2017-4-11

\section{Русский детский детектив на современном этапе}

\begin{abstract}
Аннотация
Главным героем в детском детективе является сыщик-подросток. Уровень насилия в сюжете существенно меньше, чем во взрослой модификации жанра. Современные рыночные условия провоцируют авторов к созданию скороспелых текстов. Особенно тревожным выглядит смещение ценностных ориентиров героев-детей.

Ключевые слова: Жанр. Детектив. Детский детектив. Книжные серии.

Детективная литература имеет огромную популярность во всём мире уже с середины 19 века. Исследователи данного жанра неизменно отмечают приключенческий характер сюжета детектива и строгую логичность в его построении, связанные с расследованием преступления, лежащего в основе сюжета. Так, Н.Н.Вольский даёт такое определение жанра: «Детектив - это литературное произведение, в котором на доступном широкому кругу читателей бытовом материале демонстрируется акт диалектического снятия логического противоречия (решения детективной загадки). Необходимостью наличия в детективе логического противоречия, тезис и антитезис которого одинаково истинны, обусловлены некоторые характерные особенности детективного жанра - его гипердетерминированность, гиперлогичность, отсутствие случайных совпадений и ошибок». Возможно и такое определение: «Детектив - жанр литературы, основанный на описании истории совершения и разоблачения преступления, выявления преступника. Фабула детектива организована вокруг разгадывания загадки, связанной с убийством, ограблением, аферой и т.П.... Герои - это преступник, жертва, сыщик и повествователь».

Особая разновидность детективного жанра, предназначенная для детского чтения, появляется в 20 в. Основные жанровые признаки этой разновидности те же, однако в детском детективе роль сыщика выполняет ребёнок. К тому же, уровень насилия в этой жанровой разновидности должен быть ниже, чем во
\end{abstract}


«взрослом» детективе. В российской литературе данная жанровая разновидность до последнего времени была относительно редкой: «Кортик», «Бронзовая птица», «Выстрел» А.Рыбакова; «Приключения Васи Куролесова» Ю.Коваля и нек. др. Сегодняшний книжный рынок поистине перенасыщен детским детективом, отечественным и переводным. Некоторые издательства, как например, «Эксмо», выпускают обширные книжные серии.

В качестве существенных особенностей современного детского детектива, существующего в условиях отсутствия цензуры (а зачастую - элементарного контроля художественного качества со стороны издателей) и жёсткой рыночной конкуренции, нужно отметить следующие.

Во-первых, сюжеты детских детективов непосредственно связаны с изменившейся в стране реальностью: расследования детей-сыщиков приводят их к изготовителям поддельных акцизных марок, торговцам оружием, мошенникам, обирающим пенсионерок и пр.

Во-вторых, рыночные условия провоцируют авторов к созданию скороспелых текстов, которые трудно назвать художественными произведениями - настолько низок их уровень. При этом авторы зачастую не дают себе труда чётко выстроить сюжет, что является необходимым требованием поэтики жанра: действие топчется на месте, эпизоды затянуты, действие разбавляется пустыми диалогами, не имеющими прямого отношения к развитию сюжета.

В-третьих, особенно тревожным выглядит смещение ценностных ориентиров героев-детей. Так, подростки живо интересуются школьным конкурсом красоты и отзываются с пренебрежением о книгах русских классиков, которые позиционируются как тяжкая и никому не нужная обуза. В другой повести тех же авторов группа подростков, находящихся на отдыхе в летнем лагере, от скуки с упорством, достойным лучшего применения, стараются взломать замок, которым прикреплена к причалу лодка, а потом и замок сарая, где она хранится. По замыслу авторов, оправдывает поведение героев тот факт, что лодка принадлежит злоумышленникам (впрочем, об этом подростки не знали, когда портили чужое имущество). Героя-подростка из повести С.Веселова удручает тот факт, что его отец - научный работник, преданный своему делу, что он не является, например, богатым бизнесменом и т.п. С целью поднять свой авторитет среди сверстников, мальчик объявляет, что его отец - киллер, и при этом никакие нравственные сомнения его не мучают.

Сказанное позволяет весьма негативно оценивать тенденции современного рынка детской литературы и предъявляет повышенные требования к профессиональной подготовке будущих школьных учителей в плане формирования у них достойного художественного вкуса. 


\section{Литература}

1. Вольский Н.Н. Загадочная логика: Детектив как модель диалектического мышления. // www.metodolog.ru/00926/00926.html

2. Купина Н.А., Литовская М.А., Николина Н.А. Массовая литература сегодня. М., Флинта. 2009. С.107-109.

3. Иванов А., Устинова А. Загадка туристического агентства. М, Эксмо. 2001.

4. Иванов А., Устинова А. Загадка брошенной лодки. М., Эксмо. 2002.

5. Веселов С. Мой папа - киллер. М., Эксмо. 2000. 